\title{
ON THE DIVERSITY OF MOLLUSC INTERMEDIATE HOSTS OF ANGIOSTRONGYLUS COSTARICENSIS MORERA \& CESPEDES, 1971 IN SOUTHERN BRAZIL
}

\author{
CARLOS GRAEFF TEIXEIRA; SILVANA C. THIENGO*; JOSÉ WILLIBALDO THOME;

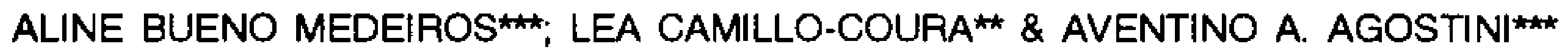

\begin{abstract}
Instituto de Ciências Biológicas, Pontificia Universidade Católica do Rio Grande do Sul, 90619-900, Porto Alegre, RS, Brasil *Departamento de Malacologia **Departamento de Medicina Tropical, Instituto Oswaldo Cruz, Av. Brasil 4365, $21045-900$ Rio de Janeiro, RJ, Brasil ***Instituto de Ciências Biológicas, Universidade de Passo Fundo, 99052-630, Passo Fundo, RS, Brasil
\end{abstract}

Veronicellid slugs are considered the most important intermediate hosts of Angiostrongylus costaricensis, an intra-arterial nematode of rodents. Studies undertaken in three localities in southern Brazil led to identification of molluscs other than veronicellid slugs as hosts of A. costaricensis: Limax maximus, Limax flavus and Bradybaena similaris. These data indicate a low host specificity of larval stages of A. costaricensis, as it has been reported to other congeneric species.

Key words: Angiostrongylus costaricensis - Limax maximus - Limax flavus - Bradybaena similaris Megalobulimus abbreviatus - abdominal angiostrongyliasis - veronicellid slugs

Angiostrongylus costaricensis Morera \& Cespedes, 1971, is a parasitic nematode of the mesenteric arterial system in rodents (Morera, 1973). Severe ischemic and inflammatory intestinal lesions may result from accidental human infection (Cespedes et al., 1967; GraeffTeixeira et al., 1991b).

Veronicellid slugs have been identified as the most important intermediate hosts: Vaginulus plebeius from Costa Rica and Ecuador (Morera \& Ash, 1970; Morera et al., 1983), a nonidentified slug from Honduras (Kaminsky et al., 1987; Morera et al., 1988) and Phyllocaulis variegatus.

We report here a search for infected molluscs in three endemic areas where no veronicellid slugs could be found.

\section{MATERIALS AND METHODS}

A nocturnal search for terrestrial molluscs was undertaken near the home of patients from three localities in the southern States of Rio Grande do Sul (RS) and Paraná (PR): 1. Macegal (Arvorezinha, RS; $28^{\circ} 45^{\prime} \mathrm{S}, 52^{\circ} \mathrm{W}$ ); 2.

Received 30 December 1992.

Accepted 8 June 1993.
Itha Vermelha (Palmitinho, RS; $27^{\circ} 14^{\prime} \mathrm{S}, 53^{\circ}$ $40^{\prime} \mathrm{W}$; 3. Coronel Vivida (PR, $26^{\circ} \mathrm{S}, 52^{\circ}$ $32^{\prime} \mathrm{W}$ ). The field work was performed in autumn of 1988 (1) and 1991 (2 and 3).

The cephalopodal mass of shelled molluscs or the eviscerated body of slugs were individually minced and incubated for $6 \mathrm{hr}$ in a $0.7 \% \mathrm{HCl}$ solution, at room temperature with occasional agitation. The minced feet of Megalobulinus abbreviatus were digested with pepsin (Sigma P7125 600-1000 U/ml), at a concentration of $4 \mathrm{mg} \%$ in a $0.7 \% \mathrm{HCl}$ solution, for $3 \mathrm{hr}$ at $37^{\circ} \mathrm{C}$. These preparations were left in Baermann funnels and the sediment was examined after $6 \mathrm{hr}$. The morphology of the tail was used as diagnostic criterion. A number of larvae inoculated into Swiss mice and the adult worms recovered 50 days postinfection were studied to confirm the identification of $A$. costaricensis (Morera, 1973).

\section{RESULTS}

Only empty shells of $M$. abbreviatus were found in Macegal and Ilha Vermelha, and 32 specimens were later sent from Macegal and examined in the laboratory. In one instance, a few larvae with a transversal groove at the tail were recovered, but failed to develop into adult A. costaricensis when inoculated into mice. 
In Coronel Vivida, three species of terrestrial molluscs were found infected: Limax maximus (40 positive/143 specimens $=28 \%$ ), Bradybaena similaris $(6 / 136=4.4 \%)$, Limax flavus $(2 / 12=17 \%)$. Seven specimens of Deroceras laeve were negative.

\section{DISCUSSION}

Veronicellid slugs occur in large number in Central America, where they are considered agricultural pests and the most important intermediate hosts of $A$. costaricensis (Morera, 1973; Morera et al., 1988). P. variegatus, a widespread species in Paraguay, north of Argentina and Uruguay, was the first intermediate host known in Brazil (Thomé, 1976; GraeffTeixeira et al., 1989).

The enzootic foci in Macegal (RS) has been studied since 1988, when two wild rodents, Oryzomys nigripes and Oryzomys ratticeps, were identified as definitive hosts (GraeffTeixeira et al., 1990). Several searches failed to demonstrate the presence of veronicellid slugs and only a giant land snail, $M$. abbreviatus, has been detected in Macegal and Itha Vermelha, a valley next the Uruguay River. Both empty shells and live specimens have been collected in residual forests, in cultivated land and near the houses. Children are used to play with these molluscs, providing an opportunity for infection.

Although infection of $M$. abbreviatus has not been fully demonstrated, one should not discard the possibility of these land snails playing an important role in the original wild cycle of this parasite.

The southwest region of Paraná, like western Santa Catarina and northern Rio Grande do Sul, are endemic areas for abdominal angiostrongyliasis (Ayala, 1987; GraeffTeixeira, 1991a). The third area studied here was identified after diagnosing a patient in Coronel Vivida (PR). A careful search failed again to find veronicellid slugs, but revealed a huge population of $L$. maximus highly infected (prevalence of $28 \%$ ) with $A$. costaricensis. These slugs could be found everywhere next the houses, especially in the vegetable gardens. The high number of infected specimens and the peridomiciliar distribution of $L$. maximus point out the importance of this limacid slug as intermediate host of $A$. costaricensis in Coronel Vivida.
The failure in collecting veronicellids in these areas, and the finding of infected limacid slugs and $B$. similaris, indicate a low specifity of larval stages of $A$. costaricensis. The same has also been reported to other congeneric species, Angiostrongylus cantonensis, the etiological agent of eosinophilic meningoencephalitis in Asia and Oceania (Alicata, 1965) and Angiostrongylus vasorum, a parasite of the circulatory system of dogs (Rosen et al., 1970).

The high prevalence in seroepidemiological studies in human populations (unpublished data), and the lack of an effective chemotherapy, justify the importance of a preventive approach to abdominal angiostrongyliasis as a health problem. Prophylact recommendations are required and their effectiveness depends on epidemiological studies concerning, among other subjects, the focal occurrence of this parasite and the diversity of intermediate hosts.

\section{ACKNOWLEDGEMENTS}

To Dr José Luis M. Leme, who identified Megalobulimus abbreviatus and to Idiomar Cavalli for sending us these molluscs. To Dr W. Lobato Paraense for criticism of this paper.

\section{REFERENCES}

ALICATA, J. E., 1965. Biology and distribution of the rat lungworm, Angiostrongy/us cantonensis, and its relationship to eosinophilic meningoencephalitis and other neurological disorders of man and animals. Adv. Parasitol., 3: 223-248.

AYALA, M. A. R., 1987. Angiostrongiloidose abdominal. Seis casos observados no Paraná e Santa Catarina, Brasil. Mem. Inst. Oswaldo Cruz, 82: 29. 36.

CESPEDES, R.; SALAS, J.; MEKBEL, S.; TROPER, L.; MULLNER, F.; MORERA, P., 1967. Granulomas entéricos y linfaticos con intensa eosinofilia tisular producidos por un estrongilideo (Strongylata): I. Patologia. Acta med. Costarr., 10: 235-255.

GRAEFF-TEIXEIRA, C.; AVILA-PIRES, F. D.; MACHADO, R. C. C.; CAMILLO-COURA, L. \& LENZI, H. L., 1990. Identificação de roedores silvestres como hospedeiros do Angiostrongylus costaricensis no sul do Brasil. Rev. Inst. Med. Trop. São Paulo, 32: 147-150.

GRAEFF-TEIXEIRA, C.; CAMILLO-COURA, L. \& LENZI, H. L., 199la. Clinical and epidemiological studies on abdominal angiostrongyliasis in southern Brazil. Rev. Inst. Med. Trop. São Paulo, 33: 375-380.

GRAEFF-TELXEIRA, A.; CAMILLO-COURA, L. \& LENZI, H. L., 1991b. Histopathological criteria for diagnosis of abdominal angiostrongyliasis. Parasitology Research, 77: 606-61l. 
GRAEFF-TEIXEIRA; C.; THOME, J. W.; PINTO, S. C. C.; CAMILLO-COURA, L. \& LENZI, H. L., 1989. Phyllocaulis variegatus - an intermediate host of Angiostrongylus costaricensis in south Brazil. Mem. Inst. Oswaldo Cruz, 84: 65-68.

KAMINSKY, R G.; ANDREWS, K. \& MORAN, R, 1987. Angiostrongylus costaricensis en babosa en Honduras. Estudio preliminar. Rev. Med. Hondur. 55: 4-8.

MORERA, P., 1973. Life History and Redescription of Angiostrongy/us costaricensis Morera y Céspedes, 1971. Am. J. Trop. Med. Hyg., 22: 613-621.

MORERA, P.; ANDREWS, K. L. \& RUEDA, D., 1988. The intermediate host of Angiostrongy/us costaricensis in Honduras. Rev. Biol. Trop. (Costa Rica),
36: 575-576.

MORERA, P. \& ASH, L. R, 1970. Investigacion del huesped intermediario de Angiostrongylus costaricensis (Morera y Céspedes, 1971). Bol. Chileno Parasitol., 25: 135.

MORERA, P. LAZO, R.; URQUIZO, J. \& LLAGUNO, M., 1983. First record of Angiostrongylus costaricensis Morera and Céspedes, 1971 in Ecuador. Am. J. Trop. Med. Hyg., 32: 1460-1461.

ROSEN, L.; ASH, L. R. \& WALLACE, G. D., 1970. Life history of the canine lungworm Angiostrongylus vasorum (Baillet). Am. J. Vet. Res., 31: 13t-143.

THOME, J. W., 1976. Revisão do gênero Phylłocaulis Colosi, 1922 (Mollusca: Veronicellidae). Iheringia. Sér. Zool., Porto Alegre, 49: 67-90. 